\title{
Effect of different organic manures and fertilizers on growth and yield of knol-khol (Brassica oleracea var. gongylodes L.)
}

\author{
Md. Anichhul Islamª, Md. Yamin Kabira, Nubayra Tasnim Shuvrab, Md. Amirul Islamc, Md. Hasibur Rahaman \\ Hera $^{\mathrm{d}^{*}}$
}

aAgrotechnology Discipline, Khulna University, Bangladesh

bDepartment of Horticulture, Bangladesh Agricultural University, Mymensingh 2202, Bangladesh

'Sustainable Intensification Program, International Maize and Wheat Improvement Center, Dhaka, Bangladesh

dPlant Pathology Division, Bangladesh Rice Research Institute, Gazipur 1701, Bangladesh

*Corresponding Author Email: hasibhera22@gmail.com

\section{Doi: $10.2478 / \mathrm{mjhr}-2020-0010$}

\begin{abstract}
:
A field experiment was carried out to investigate the effect of different manures and fertilizers on the growth and yield of knol-khol (Brassica oleracea var. gongylodes) at Dr. Purnendu Gain Field Laboratory of Agrotechnology Discipline, Khulna University, Khulna from November 2014 to February 2015. The single factor experiment comprised of different types of fertilizers and manures viz., $\mathrm{T}_{0}$ (Control), $\mathrm{T}_{1}$ (Recommended doses of NPK), $\mathrm{T}_{2}$ (Cow dung), $\mathrm{T}_{3}$ (Vermicompost), $\mathrm{T}_{4}$ (Poultry manure), $\mathrm{T}_{5}$ ( $50 \%$ Cow dung + $50 \%$ NPK), $\mathrm{T}_{6}$ (50\% Vermicompost + 50\% Cow dung), $\mathrm{T}_{7}$ (50\% Vermicompost + $50 \%$ Poultry manure $)$ and $\mathrm{T}_{8}(25 \%$ Cow dung+ 25\% Vermicompost $+25 \%$ Poultry manure $+25 \%$ NPK). The Experiment was laid out in Randomized Complete Block Design (RCBD) with four replications. The maximum plant height was obtained from the treatment $\mathrm{T}_{1}$ at 25,35 and 45 Days after transplanting (DAT). The maximum spread of canopy was $36.75 \mathrm{~cm}, 52.50 \mathrm{~cm}$ and $66.05 \mathrm{~cm}$ from the treatment $\mathrm{T}_{3}, \mathrm{~T}_{7}$ and $\mathrm{T}_{2}$, respectively. The maximum economic yield ( $21.92 \mathrm{t} /$ ha) and biological yield (40.083 t/ha) were found in the treatment $\mathrm{T}_{1}$ and $\mathrm{T}_{7}$, respectively. Highest benefit cost ratio (3.07) was obtained from the treatment $\mathrm{T}_{1}$ whilethe minimum (0.57) was obtained from $\mathrm{T}_{3}$ which indicates that high cost of vermicompost affect net return severely. Although, $\mathrm{T}_{1}$ produced maximum benefit cost ratio, the treatment $\mathrm{T}_{4}$ and $\mathrm{T}_{2}$ are very close to $\mathrm{T}_{1}$ and also statistically similar. So, we can consider poultry manure and cow dung for our soil health, environmental benefits and ecological safety.
\end{abstract}

Keywords: Growth; Knob, Knol-khol, Organic matter, Yield

\subsection{Introduction}

Knol-khol (Brassica oleracea var. gongylodes L.) belongs to the family Brassicaceae that is the German name for cabbage turnip, also called kohlrabi, which resembles an above ground turnip originated in the coastal countries of Western Europe [1]. The fleshy enlargement of the stem develops entirely above the ground, called knob and is used as a vegetable. It is an excellent vegetable if it is used before it becomes tough and fibrous. It is a member of the cole crops and is an excellent vegetable. It is high in minerals and vitamins A and C. It contains adequate amount of water ( $90.3 \mathrm{~g})$, calories (29.0 g), protein (2.0 $\mathrm{g})$, carbohydrate $(6.6 \mathrm{~g})$, fibre $(1.0 \mathrm{~g})$ and ash $(\mathrm{l} .0 \mathrm{~g})$ per $100 \mathrm{~g}$ of edible stem. It also contains satisfactory amount of calcium (41.0 mg), phosphorus (51.0 $\mathrm{mg}$ ), iron (0.5 mg), sodium (8.0 mg), potassium (372.0 mg), vitamin A (20.0 mg), thiamin (0.06 mg), riboflavin (0.04 mg), niacin (0.03 mg), and vitamin C $(66.0 \mathrm{mg})$ per $100 \mathrm{~g}$ of above ground stem [2]. Basically, edible part of knol-khol is knob, which is form swelling of the stem tissue above the cotyledons. The crop has tremendous medicinal properties like, acidosis, asthma, cancer, cholesterol level, heart problems, indigestion, muscle and nerve functions, prostate and colon cancer, skin problems, weight loss etc [3].

Production of knol-khol depends on many factors such as quality of seed, variety, plant spacing, fertilizer and proper management practices. The actual yield of knol-khol is very low against the potential yield due to lack of awareness regarding its nutritive value and method of production. This can be bridged up by adopting modern agronomic techniques like planting methods, controlled irrigation, hybrid variety and increased nutritional status of the soil through balanced fertilizer application. The main component of sustainable agriculture is the utilization of all the three major nutrients sources like, inorganic, organic and biofertilizers. These three components have various advantages such as, they enhance the rapid availability of various essential nutrients, improves the soil's physical, chemical, and biological properties along with conserving the moisture-holding capacity, fixed the atmospheric nitrogen and transformed the unavailable to available forms of nutrients [4,5]. Knol-khol responds greatly to major essential nutrients like $\mathrm{N}$, $\mathrm{P}$ and $\mathrm{K}$ in respect of its growth and yield [6].

In tropical to subtropical regions the soils are seriously impoverished in plant nutrients due to intensive weathering and leaching. Plants require food for growth and development in the form of proper doses of NPK. Nitrogen is a part of chlorophyll 1 molecule, amino acid, proteins, nucleic acid and pigments [7]. Addition of nitrogen enhances vegetative growth and its deficiency leads to stunted growth with small yellow leaves and low production [8]. Phosphorus plays a vital role in several key physiological processes, viz. photosynthesis, respiration, energy storage and transfer, cell division and cell enlargement. It is an important structural component of many biochemical viz., nucleic acids (DNA, RNA), co-enzymes, nucleotides, phospholipids and sugar phosphate. It stimulates root growth, blooming, fruit setting and seed formation [9]. Potassium is considered essential in photosynthesis, sugar translocation, nitrogen metabolism, enzyme activation, stomatal opening, water relation and growth of meristematic tissue. It acts as chemical traffic policeman, root booster, stalk strengtheners, protein builder, breathing regulator and retard the diseases, but it is not effective without its co-efficient such as N and P [10].

Again use of organic matter in crop production may have many advantages over inorganic fertilizer. Organic matter reduces soil erosion, increases water holding capacity, improves physiochemical and biological conditions of the soil. Besides nitrogen, phosphorus, potassium and sulfur, a considerable amount of micronutrients is also present in organic matter. Knol-khol is a short duration crop so easily soluble organic manure should be applied for its cultivation. Organic manure helps to conservation of soil moisture. Available soil moisture also helps taking other nutrients for the plants. With the available soil moisture nitrogen fertilizer also may be available to the plants. In this way organic manure helps up taking of nitrogen fertilizer [11].

Organic fertilizers contain mineral nutrients in the form of complex organic molecules and the levels of nutrients are much lower than inorganic fertilizers. They also have a longer residual effect than inorganic fertilizers. Inorganic fertilizers are specially made to provide essential nutrients faster even during unfavorable conditions such as autumn and spring. In other words, inorganic fertilizers do not depend on the activity of microbes to release nutrients. Therefore, inorganic fertilizers are required in smaller amounts and the yare easy to store as well as to apply to the soil compared to organic fertilizers. Inorganic fertilizers do not supply humus to the soil, so the nutrient and water holding capacity of the soil may be less than that of organic fertilized soil. This lower capacity as well as high solubility of inorganic fertilizer leads to faster leaching of nutrients (nitrogen) from the soil [12].

The interactive advantages of combining inorganic and organic sources of nutrient generally provide superior status to use of each component separately. The judicious application of organic and inorganic fertilizers have maintained long term soil fertility and sustained a higher level of productivity.

Bangladesh is a developing country. Most of the people living here are suffering from nutrient deficit i.e., malnutrition. Organic knol-khol can be cheap and safe vegetables with healthy soil that is our ultimate destination to produce crop. So, cultivation of knol-khol by organic manures deserve great importance. Therefore, the present study was undertaken to observe the assessment of comparative effectiveness of organic and inorganic fertilizers on growth and yield of Knol-khol and to find out best combination(s) of organic manures and inorganic fertilizers for obtaining higher economic yield. 
The field experiment was conducted at Dr. Purnendu Gain Field Laboratory, Khulna University, Khulna during the period from November 2014 to February 2015 to study the effect of organic and inorganic fertilizer on the growth and yield of knol-khol. Experimental field was located at $89^{\circ} 33^{\prime} \mathrm{E}$ Longitudes and $22^{\circ} 50^{\prime} \mathrm{N}$ Latitude at an altitude of 8 meters above the sea level [13].

A variety i.e. Early White (DEB 170) and nine different types of treatments were used in this experiment which are: $\mathrm{T}_{0}$ : Control (No fertilizer); $\mathrm{T}_{1}$ : Recommended dose of NPK (Urea, TSP, MP) (100\%); $T_{2}$ : Cow dung (CD) (100\%); $\mathrm{T}_{3}$ : Vermicompost (VC) (100\%); $\mathrm{T}_{4}$ : Poultry manure (PM)(100\%); $\mathrm{T}_{5}$ $50 \% \mathrm{NPK}+50 \% \mathrm{CD} ; \mathrm{T}_{6}: 50 \% \mathrm{CD}+50 \% \mathrm{VC} ; \mathrm{T}_{7}: 50 \% \mathrm{VC}+50 \% \mathrm{PM} ; \mathrm{T}_{8}: 25 \% \mathrm{NPK}+25 \% \mathrm{CD}+25 \% \mathrm{VC}+25 \%$ PM. The experiment was laid out in the Randomized Complete Block Design (RCBD) with four replications. Whole experimental area (25.50 m x $8.55 \mathrm{~m})$ was first divided into four blocks each block was divided into 9 unit plots and a total of $36(4 \times 9)$ unit plots were included in the experiment. The size of a unit plot was $2.25 \mathrm{~m} \times 1.2 \mathrm{~m}$. The distance between two plots was $50 \mathrm{~cm}$ and between two blocks was $75 \mathrm{~cm}$. Total area used for the experiment was 218.03 square meter.

\subsection{Raising of Seedlings}

Seedlings of knol-khol was raised at the Germplasm Center of Agrotechnology Discipline, Khulna University, Khulna, under special care in five seed beds each measuring $3 \mathrm{~m} \mathrm{x} 1 \mathrm{~m}$. Soil of the seed bed was ploughed and make the soil loose and friable. To inhibit the infestation of damping off disease, the seed beds were dried in the sun. Cow dung was applied to the prepared seed beds @ $5 \mathrm{t} / \mathrm{ha}$. Ten grams of seeds was sown in each seed bed on 25 November 2014. The seeds were covered with fine light soil after sowing to protect the young seedlings from scorching sunshine and heavy rainfall; shading was given by bamboo mat (chatai).Weeding, mulching and light watering were done from time to time for maintaining favorable environmental condition for raising healthy seedlings.

\subsection{Land preparation and fertilization}

Land was subsequently ploughed several times with a power tiller to bring about a good tilth and suitable for growing knol-khol. Weeds and stubbles were removed as from the field and big clods were broken through laddering into tiny pieces. Diazinon57 EC was used @ $650 \mathrm{ml} / \mathrm{ha}$ to treat soil for protection of young plant from the attack of insect like cutworm and mole cricket. Entire amount of well decomposed cow dung @ 20 t/ha for treatment $\mathrm{T}_{2}$, $10 \mathrm{t} / \mathrm{ha}$ for treatment $T_{5}$ and $T_{6} \& @ 5 \mathrm{t} / \mathrm{ha}$ for treatment $\mathrm{T}_{8}$ was applied at the time of initial land preparation. According to the treatment and layout whole amount of TSP and MoP and 1/3 Urea were applied after laying out of the plot and 4 days before transplanting. Again half of rest amo unt of Urea was applied 20 days after transplanting and rest half was applied 30 days after transplanting. Applied fertilizers were mixed properly with the soil of the plot using a spade.

Table 1: The doses of manures and fertilizers applied in the experiment

\begin{tabular}{|c|c|c|}
\hline Treatments & Dose (per hectare) & Dose (Per plot) \\
\hline $\mathrm{T}_{0}$ & Control (No fertilizer) & 0 kg Cow dung $+0 \mathrm{~kg}$ Urea $+0 \mathrm{~kg}$ TSP $+0 \mathrm{~kg}$ MoP \\
\hline $\mathrm{T}_{1}$ & $300 \mathrm{~kg}$ Urea $+300 \mathrm{~kg}$ TSP $+250 \mathrm{~kg}$ MoP & 81 g Urea+81 g TSP+ 67.5 g MoP \\
\hline $\mathrm{T}_{2}$ & 20 ton Cow dung & $5.4 \mathrm{~kg}$ \\
\hline $\mathrm{T}_{3}$ & 20 ton Vernicompost & $5.4 \mathrm{~kg}$ \\
\hline $\mathrm{T}_{4}$ & 12 ton Poultry Manure & $3.24 \mathrm{~kg}$ \\
\hline $\mathrm{T}_{5}$ & $(150+150+125) \mathrm{kg} \mathrm{NPK}+10$ ton Cow dung & $41 \mathrm{~g}$ Urea+41 g TSP+ $34 \mathrm{~g} \mathrm{MoP}+2.7 \mathrm{~kg}$ Cow dung \\
\hline $\mathrm{T}_{6}$ & 10 ton cow dung+ 10 ton Vermicompost & 2.7 kg Cow dung + 2.7 kg Vermicompost \\
\hline $\mathrm{T}_{7}$ & 10 ton Vermicompost+ 6 ton Poultry manure & $2.7 \mathrm{~kg}$ Vermicompost $+1.62 \mathrm{~kg}$ Poultry manure \\
\hline $\mathrm{T}_{8}$ & $(75+75+62.5) \mathrm{kg} N P K+5$ ton $\mathrm{CD}+5$ ton $\mathrm{VC}+3$ ton $\mathrm{PM}$ & $21 \mathrm{~g}$ Urea+21 g TSP +17 g MoP+1.35 kg CD+1.35 kg VC +0.82 kg PM \\
\hline
\end{tabular}

\subsection{Transplanting of seedlings}

Seedlings were transplanted in the experimental plots on December 25, 2014. Healthy and uniformed sized, 30 days old seedlings were used as transplanting materials. Seed beds were watered before uprooting of the seedlings to minimize damage to the roots of seedlings. Transplanting was done in the afternoon at a spacing of $45 \mathrm{~cm} \times 30 \mathrm{~cm}$ accommodating 20 plants in each unit plot. After transplanting, the seedlings were watered immediately. Banana leaf sheath pieces were used to protect the seedlings from scorching sun. Until the seedlings were established, shading and watering were continued for 5 days. To fill the gap when required, a number of seedlings were also planted in the border of the experimental plots.

\subsection{Crop management and harvesting}

Gap filling was done as and when necessary. Hand weeding was done at 15, 30 and 45 days after transplanting to keep the plots free from weeds during the entire growing period. Light irrigation was given by a watering can at every morning and afternoon following transplanting and it was continued for a week for rapid and well establishment. Irrigation was applied at 20, 35 days after transplanting. At the time of establishment of seedling in the field the attack of soil insects was a serious problem. Dursban 29 EC @ 3\% was applied against the soil born insects like mole crickets, field crickets and cut worm. Knol-khol was harvested at maturity when the edible part of the plants formed well-sized.

\subsection{Data collection \\ 2.6.1. Phenological characters}

Data was recorded from 06 randomly selected plants from the middle rows of each unit plot during the course of experiment. Height of plant and number of leaves were recorded at 15, 25, 35, 45 and 55 days after transplanting (DAT). Fallen leaves were counted on the basis of scar marks on the stem introduced by the petiole of the leaves. Crown spread was measured in centimeter by taking the mean diameter of the canopy of an individual plant in several directions. Fresh weight of leaves was taken at harvest following average weight of leaves per plant was recorded in gram. Fresh weight of the edible part per plant and fresh weight of root was recorded and expressed in both gram and kilogram. Selected six knobs were sectioned vertically in the middle position with a sharp knife. The diameter of the knob was measured in centimeter with a scale as the horizontal distance from one side to another side of the sectioned knob. Thickness of knob was measured in centimeter with a scale as the vertical distance from one side to another side of the knob and expressed in $\mathrm{cm}$. The main root was pulled out of soil carefully at harvest and the soil was washed out by water and then the number of roots per plant was counted. The distance between the bases to the tip of the root was measured in $\mathrm{cm}$ at harvest with the help of meter scale for determining the length of root. At first the fresh weight of leaves per plant was recorded then one hundred gram of representing fresh leaves was sun dried for three days. Then the leaves were dried in an oven at $70^{\circ} \mathrm{C}$ for 72 hours. Then dry weight was taken and expressed in percentage. After recording the fresh weight of roots per plant $100 \mathrm{~g}$ of root was taken, chopped and sun dried. The sundried roots were than dried in an oven at $70^{\circ} \mathrm{C}$ for 72 hours. Then weight the dried root and expressed in percentage.

\subsubsection{Biological yield, Economic yield and Harvest Index}

Biological yield of a knol-khol was measured as the whole plant weight including the leaves of all the plant of a plot while economic yield was taken as weight of edible parts of all the plants in a plot and expressed in $\mathrm{t} / \mathrm{ha}$. Economic yield included only yield of knob. Harvest index is the proportion of economic yield divided by biological yield and was expressed in percentage.

\subsubsection{Economic analysis}

Cost of production was analyzed in order to find out the most economic return under different treatment combinations. All input costs, including the cost for lease of land and interest on running capital were considered for computing the cost of production. The interests were calculated @ $12 \%$ per year for 6 month. The cost and return analyses were done in details according to the procedure followed by Alamet al. [14]. The Benefit Cost Ratio (BCR) was calculated as follows: 


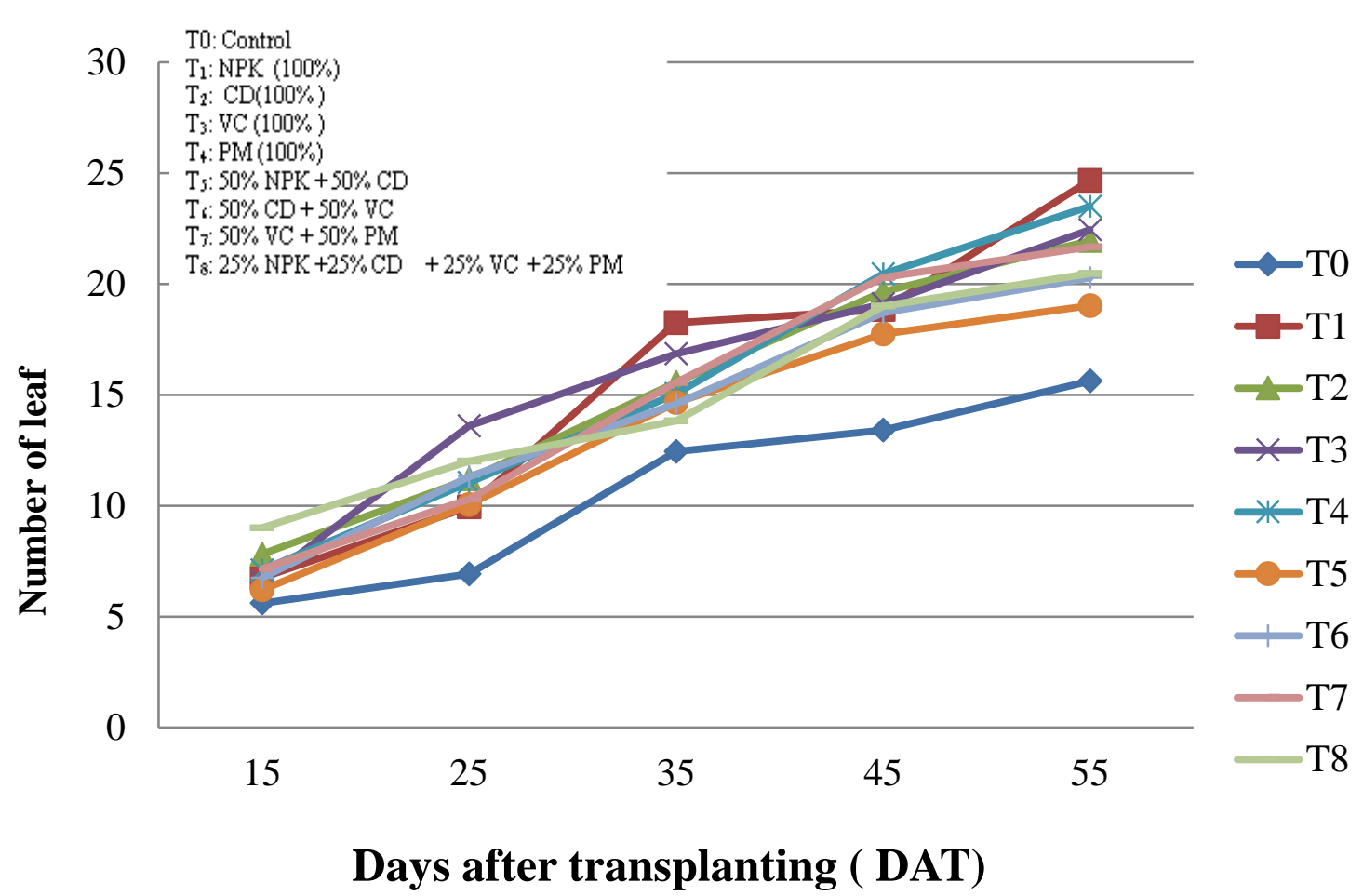

Figure 2: Number of leaves of knol-kholat different days after transplanting as influenced by manures and fertilizers.

At $25 \mathrm{DAT}$, maximum spread of plant $(36.75 \mathrm{~cm})$ was found from the treatment $\mathrm{T}_{3}$ (Vermicompost) and the minimum $(20.50 \mathrm{~cm})$ was found from the (Control)treatment. In case of $35 \mathrm{DAT}$, maximum spread of plant canopy was $(52.50 \mathrm{~cm})$ and minimum was $(41.30 \mathrm{~cm})$ from the treatment $\mathrm{T}_{7}\left(\mathrm{~T}_{7}: 50 \% \mathrm{VC}\right.$ $+50 \% \mathrm{PM}$ ) and $\mathrm{T}_{0}$ (Control), respectively. At, $45 \mathrm{DAT}$, maximum spread of plant canopy was $66.05 \mathrm{~cm}$ and minimum was $46.10 \mathrm{~cm}$ from the treatments $\mathrm{T}_{2}$ (Cow dung) and To (Control) respectively.

It was observed that the interaction effects of different organic manure and different fertilizers were significant on spread of plant canopy. This may be due to the fact that the presence of all the three major elements in a suitable combination enhanced the vegetative growth of the plants. Combination of poultry manures with cow dung or vermicompost gave the maximum spread of plant canopy when it is grown in early rabi season $[18,19]$

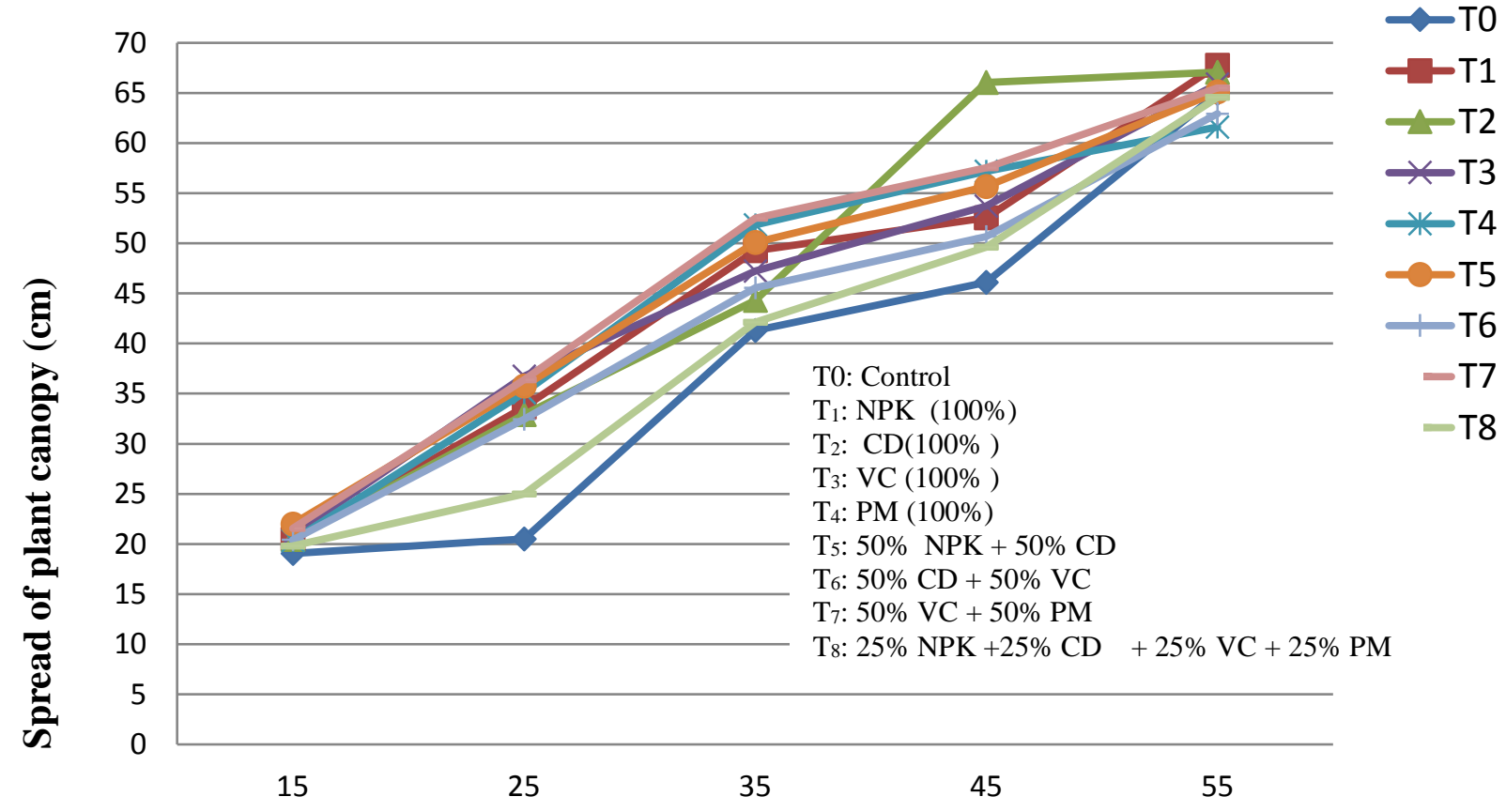

Days after transplanting ( DAT)

Figure 3: Spread of plant canopy of knol-kholat different days after transplanting as influenced by manures and fertilizers.

\subsection{Fresh and dry weight of leaves per plant}

Fresh weight and dry weight of leaves varied significantly by the application of different manures and fertilizers. Maximum fresh weight of leaves (235 g) was recorded when the treatment $\mathrm{T}_{2}$ i.e.,(Cow dung) was applied while highest dry weight $(23.95 \%)$ of fresh weight was recorded with the treatment $\mathrm{T}_{8}$ (25\% Cow dung+ 25\% Vermicompost+ 25\% Poultry manure $+25 \%$ Recommended doses of NPK)respectively. On the other hand, the minimum fresh weight (104.5 g) and dry weight (19.44\%) were found from the (Control)treatment $\mathrm{T}_{0}$ (Table 2).

\subsection{Diameter of knob}

Effect of different manures and fertilizers had significant influence on the diameter (Table 2). The maximum diameter of knob (10.52 cm) was found with the treatment $\mathrm{T}_{6}(50 \%$ Vermicompost $+50 \%$ Cow dung) and the minimum diameter $(5.25 \mathrm{~cm})$ was obtained from (Control) treatment. As knol-khol is a 
short duration crops and highly feeding crops it requires readily available nutrients.

\subsection{Knob yield per plant and knob yield per plot}

Different organic manures and fertilizer had significant effect on fresh weight of knob per plant as well as per plot (Table 2). Maximum fresh weight of knob plant ( $328.75 \mathrm{~g}$ ) and knob per plot ( $6.575 \mathrm{~kg}$ ) were obtained from the treatment $\mathrm{T}_{1}$ (Recommended doses of NPK) and the minimum fresh weight of knob ( $187.5 \mathrm{~g}$ ) as well as knob yield per plot ( $3.75 \mathrm{~kg}$ ) were found from the $\mathrm{T}_{0}$ (Control)treatment. Treatment $\mathrm{T}_{4}$ (Poultry manure) produces second highest yield of knob per plot. The maximum weight of single tuber might be due to balanced fertilization because normal metabolic processes can continue only in the presence of an optimum level of nitrogen, phosphorus etc. Potassium plays its role in the promotion of growth and meristematic tissues. Interaction effects of different organic manure and fertilizers treatment were significant on fresh weight of knob. Fink [20] found that inorganic fertilizers gave the highest fresh weight of knob.

\subsection{Number of lateral roots}

Effect of different manures and fertilizers had no significant influence on the production of lateral roots of knol-khol. Maximum number of lateral roots (32.25) was obtained when the treatment $\mathrm{T}_{8}$ i.e., (25\% Cow dung $+25 \%$ Vermicompost $+25 \%$ Poultry manure $\left.+25 \% \mathrm{NPK}\right)$ was applied and minimum $(28.2)$ was recorded from the treatment $\mathrm{T}_{0}$ (Control) ( Table. 2)

Number of lateral roots increased gradually with balanced nutrient supply. From the above results, it was noted that different manures and synthetic fertilizers when combinedly used than it provides proper aeration, increase microbial activities as a result plant nutrients became available for better growth and development of roots which ultimately increased the number of lateral roots.

\subsection{Length of roots}

Effect of fertilizers revealed that there was anon significant difference among the organic manures and fertilizers in respect of average length of root (Table 2). Maximum length of root $(16.85 \mathrm{~cm})$ was recorded from the treatment $\mathrm{T}_{1}$ (Recommended doses of NPK). Minimum length (14.66 $\left.\mathrm{cm}\right)$ was found in the treatment $\mathrm{T}_{0}$ (Control).

\subsection{Fresh weight and dry weight of roots}

Different organic manures and fertilizer had significant effect on fresh weight of roots per plant (Table 2).Highest fresh weight of roots (16.25g) was recorded from the treatment $\mathrm{T}_{1}$ (Recommended doses of NPK) and the lowest (14.63 g) was found from the treatment To (Control). Contrariwise, maximum percent dry weight (40.85\%) of roots was recorded in the treatment $\mathrm{T}_{7}$ ( $50 \%$ Vermicompost $+50 \%$ Poultry manure) and minimum per cent dry weight $(21.52 \%)$ of roots was recorded in the treatment $\mathrm{T}_{0}$ (Control)treatment. This was due to the balanced application of fertilizers, which significantly influenced the root growth of knol-khol. Interaction effects of different organic manure and fertilizers treatment were significant in this regard.

\subsection{Economic yield}

Effects of different manures and fertilizers on economic yields of knol-khol per hectare revealed that variation among different fertilizers were statistically significant. It is obvious from the present study that the maximum marketable yield resulted from proper supply of nutrients. Highest marketable yield (21.92 t/ha) was found from treatment $\mathrm{T}_{1}$ (Recommended doses of NPK) and minimum marketable yield (12.5 $\mathrm{t} / \mathrm{ha}$ ) was found from the treatment (Control)(Table 2). It was observed that the interaction effect of different organic manures and fertilizers treatment on economic yield per hectare was statistically significant.

\subsection{Biological yield}

Biological yield per hectare was significantly influenced by the application of different fertilizers. Maximum biological yield per hectare (36.62 ton) was produced by the plants grown under the treatment $\mathrm{T}_{1}$ (Recommended doses of NPK). Then the second highest biological yield are 34.83 ton and 34.33 ton for the treatments of $\mathrm{T}_{2}$ (Cow dung) and $\mathrm{T}_{4}$ (poultry manure) which are statistically similar. While the lowest yield per hectare (21.51 ton) was found from (Control) (Table 2). It was observed that the inorganic fertilizers gave the better result than the organic manures treatment. Study of Zhang et al. [21] supports this result. Interaction effects of different organic manure and fertilizers treatment were found tobe significant for biological yield of knol-khol per hectare.

Table 2: Effect of different manures and fertilizers on growth and yield contributing characteristics of knol-khol

\begin{tabular}{|c|c|c|c|c|c|c|c|c|c|c|c|c|}
\hline \multirow{2}{*}{ Treatments } & \multirow[b]{2}{*}{$\begin{array}{l}\text { Fresh } \\
\text { weight of } \\
\text { leaves/plan } \\
t(\mathrm{gm})\end{array}$} & \multirow[b]{2}{*}{$\begin{array}{l}\text { Dry } \\
\text { weigh } \\
t \quad \text { of } \\
\text { leaves } \\
\text { (gm) }\end{array}$} & \multirow{2}{*}{$\begin{array}{l}\text { Diamete } \\
\text { r of knob } \\
(\mathrm{cm})\end{array}$} & \multirow[b]{2}{*}{$\begin{array}{l}\text { Knob } \\
\text { yield/ } \\
\text { plant } \\
\text { (g) }\end{array}$} & \multirow{2}{*}{$\begin{array}{l}\text { Knob } \\
\text { yield/plo } \\
\text { t (Kg) }\end{array}$} & \multirow[b]{2}{*}{$\begin{array}{l}\text { Numbe } \\
r \quad \text { of } \\
\text { lateral } \\
\text { roots }\end{array}$} & \multirow[b]{2}{*}{$\begin{array}{l}\text { Lengt } \\
\mathrm{h} \text { of } \\
\text { roots } \\
(\mathrm{cm})\end{array}$} & \multirow[b]{2}{*}{$\begin{array}{l}\text { Fresh } \\
\text { weigh } \\
t \quad \text { of } \\
\text { root } \\
(\mathrm{gm})\end{array}$} & \multirow[b]{2}{*}{$\begin{array}{l}\text { Dry } \\
\text { weigh } \\
t \quad \text { of } \\
\text { roots } \\
\text { (gm) }\end{array}$} & \multirow{2}{*}{$\begin{array}{l}\text { Economi } \\
\text { c yield } \\
\text { (t/ha) }\end{array}$} & \multirow{2}{*}{$\begin{array}{l}\text { Biologica } \\
\text { l Yield } \\
(\mathrm{t} / \mathrm{ha})\end{array}$} & \multirow{2}{*}{$\begin{array}{l}\text { Harves } \\
t \text { Index } \\
(\%)\end{array}$} \\
\hline & & & & & & & & & & & & \\
\hline $\mathrm{T}_{0}$ & $130.50 \mathrm{~b}$ & $\begin{array}{l}30.75 \\
c\end{array}$ & $5.25 \mathrm{c}$ & $\begin{array}{l}187.5 \\
0 \mathrm{~d}\end{array}$ & $3.75 \mathrm{~d}$ & 28.20 & 14.66 & $8.75 \mathrm{c}$ & 4.29 & $12.50 \mathrm{~d}$ & $21.52 \mathrm{c}$ & 57.81 \\
\hline $\mathrm{T}_{1}$ & $201.30 \mathrm{a}$ & $\begin{array}{l}37.85 \\
b\end{array}$ & $9.43 \mathrm{ab}$ & $\begin{array}{l}328.7 \\
5 \mathrm{a}\end{array}$ & $6.58 \mathrm{a}$ & 32.15 & 16.85 & $\begin{array}{l}13.38 \\
a b\end{array}$ & 4.33 & $21.92 \mathrm{a}$ & $40.08 \mathrm{a}$ & 59.80 \\
\hline $\mathrm{T}_{2}$ & $235.00 \mathrm{a}$ & $\begin{array}{l}46.94 \\
\mathrm{ab}\end{array}$ & $7.80 \mathrm{~b}$ & $\begin{array}{l}287.5 \\
0 \mathrm{abc}\end{array}$ & $5.75 \mathrm{abc}$ & 29.60 & 16.15 & $\begin{array}{l}13.75 \\
\text { ab }\end{array}$ & 4.63 & $19.17 \mathrm{abc}$ & $34.83 \mathrm{ab}$ & 54.91 \\
\hline $\mathrm{T}_{3}$ & $206.30 \mathrm{a}$ & $\begin{array}{l}37.03 \\
b\end{array}$ & $7.85 \mathrm{~b}$ & $\begin{array}{l}237.5 \\
0 \text { bcd }\end{array}$ & $4.75 \mathrm{bcd}$ & 31.90 & 15.80 & $\begin{array}{l}13.13 \\
a b\end{array}$ & 4.65 & $15.84 \mathrm{bcd}$ & $28.17 \mathrm{abc}$ & 56.18 \\
\hline $\mathrm{T}_{4}$ & $215.00 \mathrm{a}$ & $\begin{array}{l}43.95 \\
b\end{array}$ & $7.70 \mathrm{~b}$ & $\begin{array}{l}300.0 \\
0 \mathrm{ab}\end{array}$ & $6.00 \mathrm{ab}$ & 31.75 & 17.40 & $\begin{array}{l}16.25 \\
a\end{array}$ & 5.57 & $20.00 \mathrm{ab}$ & $34.33 \mathrm{ab}$ & 58.38 \\
\hline $\mathrm{T}_{5}$ & $218.80 \mathrm{a}$ & $\begin{array}{l}48.25 \\
a b\end{array}$ & $8.10 \mathrm{~b}$ & $\begin{array}{l}250.0 \\
0 \mathrm{a}-\mathrm{d}\end{array}$ & $5.00 \mathrm{a}-\mathrm{d}$ & 30.80 & 15.80 & $\begin{array}{l}14.63 \\
a b\end{array}$ & 5.28 & $16.67 \mathrm{abc}$ & $31.25 \mathrm{abc}$ & 53.64 \\
\hline $\mathrm{T}_{6}$ & $211.30 \mathrm{a}$ & $\begin{array}{l}44.53 \\
a b\end{array}$ & $10.52 \mathrm{a}$ & $\begin{array}{l}262.0 \\
0 \text { a-d }\end{array}$ & $5.20 \mathrm{a}-\mathrm{d}$ & 31.50 & 15.90 & $\begin{array}{l}13.63 \\
a b\end{array}$ & 5.01 & $17.41 \mathrm{abc}$ & $31.59 \mathrm{abc}$ & 55.21 \\
\hline $\mathrm{T}_{7}$ & $213.80 \mathrm{a}$ & $\begin{array}{l}40.68 \\
b\end{array}$ & $7.95 \mathrm{~b}$ & $\begin{array}{l}275.0 \\
0 \text { abc }\end{array}$ & $5.50 \mathrm{abc}$ & 32.13 & 15.90 & $\begin{array}{l}13.38 \\
a b\end{array}$ & 5.12 & $18.33 \mathrm{abc}$ & $36.62 \mathrm{ab}$ & 54.63 \\
\hline $\mathrm{T}_{8}$ & $185.10 \mathrm{a}$ & $\begin{array}{l}50.33 \\
a\end{array}$ & $7.55 \mathrm{~b}$ & $\begin{array}{l}212.5 \\
0 \mathrm{~cd}\end{array}$ & $4.25 \mathrm{~cd}$ & 32.25 & 15.22 & $\begin{array}{l}13.68 \\
\text { bc }\end{array}$ & 5.09 & $14.17 \mathrm{~cd}$ & $25.84 \mathrm{bc}$ & 52.06 \\
\hline $\begin{array}{l}\text { Level of } \\
\text { significanc } \\
\mathrm{e}\end{array}$ & $*$ & $*$ & $* *$ & $* *$ & $* *$ & NS & NS & $*$ & NS & $* *$ & $*$ & NS \\
\hline$C V(\%)$ & 24.75 & 8.32 & 13.92 & 14.86 & 14.86 & 13.24 & 12.35 & 24.49 & 23.39 & 14.86 & 23.39 & 9.17 \\
\hline
\end{tabular}

\subsection{Harvest Index}

Interaction effects of different organic manures and fertilizers treatment were found to be non-significant in case of harvest index (Table 2). Numerically the maximum harvest index was (58.80\%) and minimum was $(52.06 \%)$ for the treatment $\mathrm{T}_{1}$ (Recommended dose of $\left.\mathrm{NPK}\right)$ and $\mathrm{T}_{8}(25 \%$ Cow dung+ $25 \%$ Vermicompost $+25 \%$ Poultry manure $+25 \%$ Recommended doses of NPK), respectively. 
basis. The total cost of production under different treatments ranged between Tk.79809.00 to Tk. 181824.38 per hectare (Table 3). Among the treatment combinations, the variation was due to the cost of different organic manure and application of different fertilizers (organic, inorganic and organic-inorganic combination). Highest cost of production (Tk.181824.38/ha) was involved in the treatment $\mathrm{T}_{3}$ i.e., (Vermicompost) and the lowest Tk. 79809.00/ha was produced from treatment $\mathrm{T}_{0}$ (Control). Because the price of vermicompost was very high and also not available. Biological return from different combinations ranged between Tk.225000.00 to Tk. 394524.00 per hectare. Biological return was the total income through the sale of knob @ Tk.18000per ton at harvest. The highest biological return (Tk. 394524.00/ha) was obtained from the treatment $\mathrm{T}_{1}$ (Recommended doses of NPK). The lowest biological return Tk. 225000.00/ha was obtained from (Control)treatment. Maximum net return was Tk. 297625/ha having a benefit cost ratio of 3.07 in the treatment combination of treatment $\mathrm{T}_{1}$ (Recommended doses of NPK). On the other hand the lowest net return (Tk. 103205.62 .00/ha) and benefit cost ratio (0.57) were obtained from the treatment $\mathrm{T}_{3}$ i.e., (Vermicompost).

Thus, it was clear that the treatment combination of knol-khol with application of inorganic fertilizer gave the highest net return in the knol-kholcultivation There was a wide gap between the lowest and the highest benefit cost ratio (BCR).However, the cost and return analysis was based on the crop yield as well as factor such as cost of inputs and market price of the harvested materials, which may vary from year to year. Therefore, the cost and return analysis for a crop grown in a particular year may not represent exactly the same with crop grown in another year.

Table 3: Cost and return analysis in knol-khol production as influenced by different manures and fertilizers

\begin{tabular}{|l|l|l|l|l|l|l|}
\hline Treatment & $\begin{array}{l}\text { Economic } \\
\text { yield (t/ha) }\end{array}$ & $\begin{array}{l}\text { Income } \\
\text { tk/ha) }\end{array}$ & $\begin{array}{l}\text { Total cost } \\
\text { tk/ha) }\end{array}$ & $\begin{array}{l}\text { Net return } \\
\text { tk/ha) }\end{array}$ & $\begin{array}{l}\text { Benefit cost ratio } \\
\text { (BCR) }\end{array}$ \\
\hline $\mathrm{T}_{0}$ & $12.50 \mathrm{~d}$ & $225.00 \mathrm{c}$ & 79.81 & $145.20 \mathrm{~cd}$ & $1.82 \mathrm{~b}$ \\
\hline $\mathrm{T}_{1}$ & $21.92 \mathrm{a}$ & $394.52 \mathrm{a}$ & 96.90 & $297.60 \mathrm{a}$ & $3.07 \mathrm{a}$ \\
\hline $\mathrm{T}_{2}$ & $19.17 \mathrm{abc}$ & $344.97 \mathrm{ab}$ & 92.60 & $252.40 \mathrm{ab}$ & $2.73 \mathrm{a}$ \\
\hline $\mathrm{T}_{3}$ & $15.84 \mathrm{bcd}$ & $285.03 \mathrm{bc}$ & 181.82 & $103.20 \mathrm{~d}$ & $0.57 \mathrm{c}$ \\
\hline $\mathrm{T}_{4}$ & $20.00 \mathrm{ab}$ & $360.00 \mathrm{ab}$ & 92.50 & $267.50 \mathrm{ab}$ & $2.89 \mathrm{a}$ \\
\hline $\mathrm{T}_{5}$ & $16.67 \mathrm{a}-\mathrm{d}$ & $299.97 \mathrm{abc}$ & 94.39 & $205.60 \mathrm{abc}$ & $2.18 \mathrm{ab}$ \\
\hline $\mathrm{T}_{6}$ & $17.41 \mathrm{a}-\mathrm{d}$ & $314.95 \mathrm{abc}$ & 138.30 & $176.70 \mathrm{bcd}$ & $1.28 \mathrm{bc}$ \\
\hline $\mathrm{T}_{7}$ & $18.33 \mathrm{abc}$ & $329.98 \mathrm{ab}$ & 135.51 & $194.50 \mathrm{bcd}$ & $1.44 \mathrm{bc}$ \\
\hline $\mathrm{T}_{8}$ & $14.17 \mathrm{~cd}$ & $255.02 \mathrm{bc}$ & 112.54 & $147.00 \mathrm{~cd}$ & $1.35 \mathrm{bc}$ \\
\hline $\begin{array}{l}\text { Level } \\
\text { Significance }\end{array}$ & $* * *$ & & & $* *$ \\
\hline CV (\%) & 14.86 & 15.19 & & 23.88 & \\
\hline
\end{tabular}

** Significant at $1 \%$ level of probability
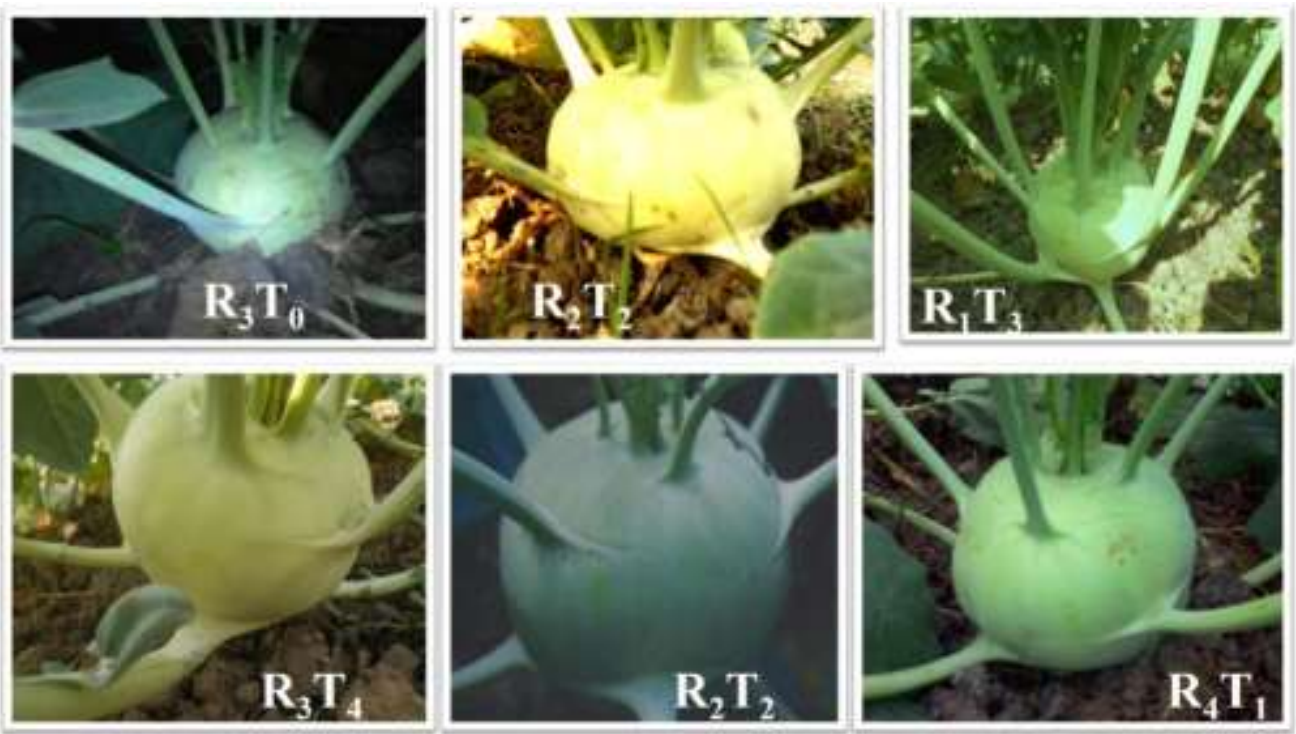

Figure 4: Photograph of knob with different treatment combinations

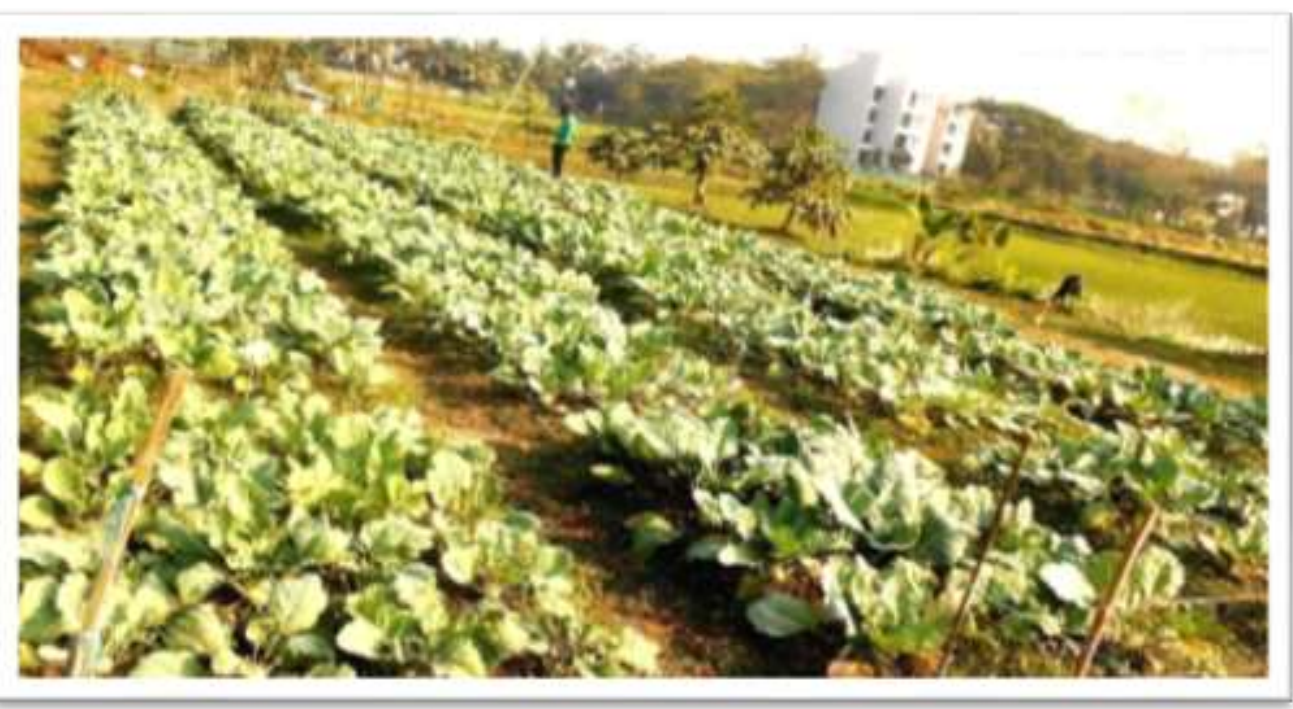

Figure 5: An overall view of experimental area. 


\subsection{Conclusion}

From the point of economic yield, it is observed that higher yield could be obtained by cultivating the knol-khol variety Early White using inorganic fertilizers under Khulna region of Bangladesh. Although recommended doses of NPK produced maximum benefit cost ratio, the treatment T4 (Poultry manure) and T2 (Cow dung) are very close to T1 (Recommended doses of NPK) and also statistically similar. So, we can consider the treatment T4 (Poultry manure) and T2 (Cow dung) for our soil health, environmental benefits and ecological safety. Further investigation may be carried out in different agro ecological zones of Bangladesh before giving final recommendation.

\subsection{References}

[1] K.G. Shanmugavelu, "Production Technology of Vegetable Crops", Oxford and IBH Publishing Co. Pvt. Ltd., Chap., 26, Pp. 364-365, 1989.

[2] J.A. Duke, and E.S. Ayensu, “Medical Plants of China”, National Book foundation, Beijing, China, Pp. $389,1985$.

[3] E.S. Chauhan, A. Tiwari, and A. Singh, "Phytochemical screening of Knol-Khol (Brassica caulorapa) owder and juice - A comparative study", International Journal of Home Science, 2, Pp. 123-126, 2016.

[4] I.J. Chaudhary, and R.P. Singh, "Applied with organic matrix based slow release bio fertilizers", International Journal of Current Microbiology and Applied Sciences, 7 Pp. 3221-3238, 2018.

[5] V. Singh, K.N. Shah, I.J. Chaudhary, D.K. Rana, "Impact assessment of different organic manures on growth, morphology and yield of onion (Allium cepa L.) cultivar", Asian Journal of Agricultural Research, 13, Pp. 20-27, 2019. Doi: 10.3923/ajar.2019.20.27.

[6] H.C. Thompson, and W.C. Kelly, “Cole Crops In: H. C. Thompson and W. C. Kelly (eds.) Vegetable crops”, McGraw Hil Book Co., New York, Pp. 230-300, 2007.

[7] L. Cavazza, and V.V. Bianco, "Fertilizer trials with vegetable crops using composted solid town refuse”, Rivista di Agronomia, 9(1), Pp. 9-16. Cited from HortAbst., 46(3), Pp. 2087, 2005.

[8] I.U. Haque, and A.K. Jakhro, "Soil and fertilizer nitrogen". Soil Sci., National Book Foundation, Islamabad, Pakistan, Pp. $266,1996$.

[9] K.S. Memon, "Soil and Fertilizers. Soil Science Department”, National Book Foundation Islamabad, Pakistan, Pp. 92, 1996.

[10] G. Chandra, "Nutrient management In: Fundamentals of Agronomy", Oxford and IBH Publishing Co. New Delhi, India. pp. 156, 1989.

[11] Anonymous, “Chinese cabbage or pet-sailn: Vegetable production in the Sub-Tropics and Tropics. (Ed.)”, Overseas Technical Cooperation Agency, Japan, 25, Pp. 146-157, 1992.

[12] L. Taiz, and E. Zeiger, "Plant physiology, the cellular basis of growth and morphogenesis", 4th edn. Cummings Publishing Company, California, Pp. $245-250,2011$.

[13] UNDP, “Land Resource Appraisal of Bangladesh for Agricultural Development”, Report 2: Agro-ecological Regions of Bangladesh. FA0, Rome, Pp. 577, 1988.

[14] M.S. Alam, T.M.T. Iqbal, M.S. Amin, and M.A. Gaffer, "Production and improvement of agronomic crop (in Bangali)", T.M. Jubair Bin Iqbal, Manik Potal, Meghi, Serajgonj, Pp. 231-239, 1989.

[15] K.A. Gomez, and A.A. Gomez, "Statistical procedure for Agricultural Research. Second Edition", A Willey Inter- Science Publication, John Willey and Sons, New York, Pp. 680, 1984.

[16] A.R. Reddy, and G. Padmaja, "Effect of phosphorus and zinc on curd yield and quality of cauliflower", J. Res. Angrau, 33(1), Pp. 65-98, 2005.

[17] S. Eimhoit, P. Schjonning, and L.J. Munkholm, "Soil aggregation - a matter of proper management". Danish Research Centre for Organic Farming. Denmark, Pp. 100-120, 2005.

[18] P.L. Krupkin, I.A. Kil-bi-I-Ya, M.A. Kakrinova, and I.Y.Y., Yaltonsky, "Effectiveness of lignin base fertilizers in Sibena”, Agriokhimiya, 12, Pp. 53-64. Cited from Hort. Abst., 64(11), Pp. 8539, 1994.

[19] K.L. Steffen, M.S. Dann, K. Fagaer, S.J. Fleischer, J.K. Harper, "Short term and long term impact of an initial large scale SMS soil amendment on vegetable crop productivity and resource use efficiency”, Comp. Sci. Util. 2(4): 75-83. Cited from Hort. Abst., 99(8), Pp. 112007, 1994.

[20] M. Fink, "Consideration of nitrogen from harvest residues in the calculation of fertilizer recommendations", Proceeding of the workshop on the ecological aspects of vegetable fertilization integrated crop production in the field, Neustadt and weinstrasse, 428, Pp. 235-242. Cited from Hort. Abst., 66(6):5003, 1998

[21] Y. Zhang, Q. Shen, J. Yu, L. Sun, H. Liu, H. Xin, and Z. Wang. "Effect of application of nitrogen fertilizers of different N forms on yields and quality of Chinese cabbage", Research Centre of Agricultural Resources and Environments, Jiangsu Academy of Agricultural Sciences Nanjing 210014, China. Jiangsu J. Agril. Sci., 20(3), Pp. 184-188, 2004. 